\title{
DESIGN OF BACK PURGING APPARATUS FOR THE WELDING OF 304L AUSTENITIC STAINLESS STEEL USING SMAW PROCESS
}

\author{
Harsimranjit Singh Randhawa \\ Student M.Tech. (Mechanical Engg.), Yadavindra College of Engineering, \\ Punjabi University Guru Kashi Campus, Bathinda, Punjab, India
}

\begin{abstract}
*Sunil Kumar
Assistant Professor (Mechanical Engg.) [Supervisor],Yadavindra College of Engineering, Punjabi University Guru Kashi Campus, Bathinda, Punjab, India *Corresponding Author Email: sunilbaghla@yahoo.co.in
\end{abstract}

\begin{abstract}
Austenitic stainless steel is a family of iron-chromium-nickel (Fe-Cr-Ni) alloy systems with low level of carbon. Minimum 10.5\% nickel is required to maintain austenitic structure at all the temperatures. The balance between the $\mathrm{Cr}$ and Ni along with Mn is normally adjusted to provide microstructure of 90-100\% austenite. The type 304L, low carbon version of austenitic stainless steel type 304, is used where welding is involved due to its resistance against inter-granular corrosion and therefore this alloy can be used "as welded condition" even in severe corrosive environments.

The main objective to produce a weld joint is to ensure sound weld which match the corrosion and mechanical properties of the base material and to choose a welding process that meets productivity requirements with little distortion as possible and minimum post welding treatments. It is equally important to give protective environment to the weld so that the damage could be minimized. In the present paper, a back purging fixture has been proposed to protect the rear side of the root pass weld metal against oxidation. An inert gas is used to protect the weld metal at the root until it is cooled to the point that oxidation no longer can occur. The authors are working further to study the effect of the designed fixture on the welding efficiency of austenitic stainless steel $304 L$.
\end{abstract}

Key words: Austenitic stainless steel 304L, SMAW, back purging, weldment

Cite this Article: Harsimranjit Singh Randhawa and Sunil Kumar, Design of Back Purging Apparatus for the Welding of 304L Austenitic Stainless Steel using SMAW Process, International Journal of Production Technology and Management (IJPTM), 8(1), 2017, pp. 1-9.

http://iaeme.com/Home/issue/IJPTM?Volume=9\&Issue $=1$ 


\section{INTRODUCTION}

Stainless steels have been defined as iron base alloys that contain at least $10.5 \%$ chromium [1]. A thin but dense self-healing chromium oxide film forms on the surface of the stainless steel provides corrosion resistance and prevent further oxidation. Nickel (plus carbon, manganese, $\&$ nitrogen) promotes the formation of austenite and chromium (plus silicon, molybdenum \& niobium) encourages the formation of ferrite [2]. Stainless steels are classified in following types depending on other alloying elements present in the alloy [3].

\subsection{Austenitic Stainless Steel}

Austenitic stainless steel is a family of iron-chromium-nickel (Fe-Cr-Ni) alloy systems with low level of carbon. Higher values of nickel (8-24\%) are added to increase the ductility of the metal and higher values of chromium (16-26\%) enhances corrosion resistance [4]. Minimum $8 \%$ nickel is required to maintain austenitic (FCC) structure at all the temperatures. The balance between the $\mathrm{Cr}$ and $\mathrm{Ni}$ together with $\mathrm{Mn}$ is normally adjusted to provide microstructure of 90 $100 \%$ austenite [4].

The $304 \mathrm{~L}$, low carbon version of austenitic stainless steel type 304, is used where welding is involved. This type of stainless steel has resistance to precipitation of chromium carbide at the grain boundaries that occurs in the temperature range of $425^{\circ} \mathrm{C}$ to $870^{\circ} \mathrm{C}$ normally attainable in the welding and thus prevents inter-granular corrosion [4]. The chromium carbide cannot be formed along the grain boundaries due to almost absence of carbon (0.03) and chromium will remain available in solution to form a characteristic protective film of chromium oxide [4]. As a result, this alloy can be used in the "as welded condition" even in severe corrosive conditions. Type 304L has slightly lower mechanical properties than austenitic stainless steel type 304 [4].

Austenitic stainless steel, type 304 and 304L, exhibit excellent resistance to corrosive environment such as in chemical, textile and petroleum industries. Type 304 and 304L are found suitable in food and dairy industries as well as rural and industrial exposure [4]. The maximum temperature to which type 304 can be exposed continuously without appreciable scaling is about $900^{\circ} \mathrm{C}[4]$.

\subsection{Ferritic Stainless Steels [4]}

The ferritic stainless steels contain $10.5-30 \% \mathrm{Cr}$, up to $0.20 \% \mathrm{C}$ and sometimes ferrite promoters $\mathrm{Al}, \mathrm{Nb}, \mathrm{Ti}$ and $\mathrm{Mo}$ [4]. They are ferritic at all temperatures, do not transform to austenite and therefore are not hardenable by heat treatment. The variation in composition within the standard limits can result in the formation of small amount of austenite during heating to temperatures near or above $870^{\circ} \mathrm{C}$, which occur during welding [4]. On cooling, this austenite transforms to martensite, thus forming duplex structure of ferrite and some martensite. The martensite reduces both the ductility and toughness and this can happen with the HAZ of ferritic steel weldments. Ferritic stainless steels have very good corrosion resistance property and suitable for low temperature use. These alloys are prone to grain growth which reduces ductility and toughness [4].

\subsection{Martensitic Stainless Steels}

The martensitic stainless steels contain $11-18 \% \mathrm{Cr}$ and comparatively higher amount of carbon that is up to $1.20 \%$ and small amount of $\mathrm{Mn}, \mathrm{Ni}$ and sometimes Mo [4]. These steels will transform to austenite on heating and therefore can be hardened by the formation of martensite on cooling and are wear resistant [4]. They have a tendency towards weld cracking on cooling when hard brittle martensite is formed [4]. 


\subsection{Duplex Stainless Steels}

Duplex stainless steels solidify as $100 \%$ ferrite nearly but half of the ferrite transforms to austenite during cooling through temperatures above $1040^{\circ} \mathrm{C}$ [4]. This behavior is found to occur by increasing $\mathrm{Cr}$ and decreasing $\mathrm{Ni}$ as compared to austenitic grades [4]. They contain roughly $24 \% \mathrm{Cr}$ and $5 \% \mathrm{Ni}$ [4]. Nitrogen is added to speed up the rate of austenite formation during cooling. Duplex stainless steels combine higher strength than austenitic stainless steels with fabrication properties similar to austenite and resistance to chloride stress corrosion cracking of ferritic stainless steels [4].

\subsection{Precipitation Hardening Stainless Steel}

There are three types of precipitation hardening stainless steels i.e. martensitic, semi austenitic and austenitic. Martensitic stainless steels can be hardened by quenching from austenitizing temperature around $1038{ }^{\circ} \mathrm{C}$ then aging between $482^{\circ} \mathrm{C}$ to $621{ }^{\circ} \mathrm{C}$ [4]. The semi austenitic stainless steels will not transform to martensite when cooled from austenitizing temperature because the martensite transformation temperature is below room temperature. These steels must be given conditioning treatment by heating in the range of $732^{\circ} \mathrm{C}$ to $954^{\circ} \mathrm{C}$ to precipitate carbon and/ or alloy elements as carbides or inter-metallic compounds [4]. The austenitic precipitation hardening stainless steels remain austenitic after quenching from the solution temperature even after substantial amount of cold work. This would include solution treating between $982^{\circ} \mathrm{C}-1121^{\circ} \mathrm{C}$, oil or water quenching and aging between $704^{\circ} \mathrm{C}-732^{\circ} \mathrm{C}$ for up to 24 hours [4].

\section{WELDABILITY OF STAINLESS STEELS}

The metallurgical feature of each group generally determines the weldability characteristics of the steel of that group. The weld ability of martensitic stainless steel is greatly affected by hardenability that can result in cold cracking. Welded joints in ferritic stainless steels have low ductility as a result of grain coarsening that is related to the absence of allotropic (phase) transformation [6]. The weldability of austenitic stainless steel is governed by their susceptibility to hot cracking as is the case with other single phase alloys with FCC crystal structure.With the precipitation hardening stainless steels, weldability is related to the mechanism associated with the transformation [6].

The austenitic class of stainless steels is considered to be weldable by common fusion and resistance welding. In fusion welding, heat is generated by electric arc stuck between the electrode and the metal to be welded. In resistance welding heat is produced by the resistance to the flow of electric current through the parts to be welded [6]. The austenitic stainless steels except for the free machining grades are the easiest to weld giving high degree of toughness even in the as welded condition. The most common type of welding processes used in fabrications are as follows: [7].

\subsection{Gas tungsten Arc Welding}

In this process an arc is established in between a tungsten electrode (non-consumable) and base metal. The arc gap is kept constant and current is controlled by the power source. The heat of arc thus produced is utilized to achieve coalescence of metals with and without filler metal [8]. Filler metal, usually available in $1 \mathrm{~m}$ length of wire, is added to the leading edge of the pool as required. The arcing electrode and molten weld pool are generally shielded by an inert gas or gas mixture of argon and/or helium [8].

The current and heat input range of the process are of the order of 10-300 A and 0.2 to 8 $\mathrm{kJ} / \mathrm{s}$ respectively [8]. The process has all positional weld capability and can produce high 
quality weld in metals such as aluminum, stainless steel and copper used in chemical plants, sheet work in aircraft engines and structures [8].

\subsection{Shielded Metal Arc welding (SMAW)}

The shielded metal arc welding (SMAW) is a versatile process with maximum flexibility and can weld many metals in all positions. It is widely used for the welding of stainless steel when the shapes and quantity do not justify automatic welding. The electrode is a solid wire covered with an extruded flux coating or cored wire [8]. There is definite relationship amongst the welding current, size of welding electrode and weld position. Stainless steels have a higher electrical resistance than ordinary steel which reduces the welding current range 25 to $50 \%$ of that used for steel electrodes [8]. Excessive current overheats the electrode coating causing loss of arc force and difficulty in directing the arc at the tip of the electrode $[4,8]$.

SMAW can be performed with either alternating or direct current using appropriate type of electrode. Direct current always gives a steadier and smoother metal transfer than that of AC [8]. This is because the polarity of DC is not always changing as it is with AC. In case of DC power source DCEP (reverse polarity) gives deeper penetration, but DCEN (straight polarity) produces a higher melting rate [8].

\section{WELD METAL MICROSTRUCTURE}

The actual microstructure obtained in austenitic chromium - nickel steel weld metal varies with composition and cooling rate. The various alloying elements used may be classified as either austenite former or ferrite formers, and depending on their combined effect the structure will be more or less austenitic. Chromium, molybdenum, silicon, niobium and aluminum are common ferrite forming elements, while nickel, carbon, nitrogen and manganese favor the formation of austenite. The combined effect of ferrite and austenite formers on the microstructure can be described by the Schaeffler diagram [9] as shown in figure 1.

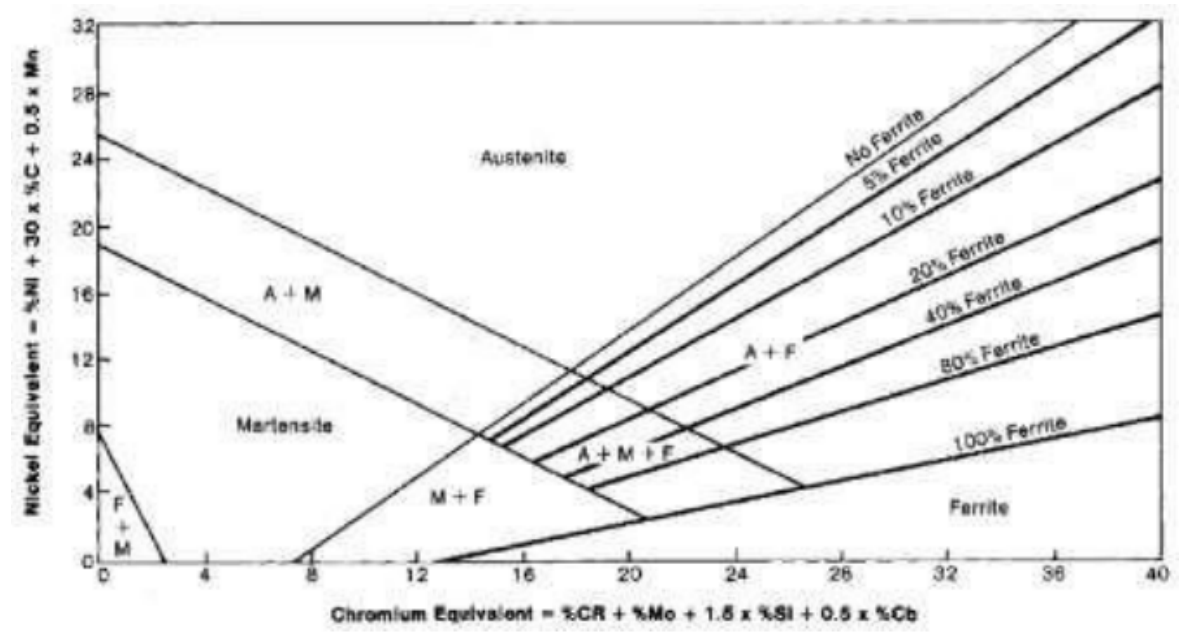

Figure 1 Schaeffler diagram for Stainless Steel [19]

The effect of austenite and ferrite formers is accounted for by numerical factors in the chromium $\left(\mathrm{Cr}_{\mathrm{eq}}\right)$ and nickel equivalent $\left(\mathrm{Ni}_{\mathrm{eq}}\right)$ in Schaeffler diagram which is commonly used for predicting room temperature ferrite content [9]. Schaefflar used the metallographic method for determining the ferrite percentage in weld metal. 


\section{RELATED WORK}

Vinoth et al. (2015) [5] have investigated a comparison of mechanical properties of 304L austenitic stainless steel weld joint produced by shielding metal arc welding (SMAW), gas metal arc welding (GMAW) and gas tungsten arc welding (GTAW) processes. The $10 \mathrm{~mm}$ thick SS 304L plate with single V joint configuration was welded with $80 \mathrm{~A}$ welding current and $20 \mathrm{~V}$ arc voltage using SMAW process. Experimental results revealed that yield strength, ultimate tensile strength and toughness were superior with the joints produced by GTAW in comparison to SMAW due to more weld penetration at the given weld deposition parameters.

Singh et al. (2013) [10] investigated the mechanical properties of multi-pass weld joint of 304 stainless steel using shielding metal arc welding process. The $16 \mathrm{~mm}$ thick 304 stainless steel plate with double $\mathrm{V}$ joint configuration was multi-pass welded taking different levels of welding currents. Inter-pass temperature was kept $175^{\circ} \mathrm{C}-200^{\circ} \mathrm{C}$. It was concluded that the weld joint deposited using low heat input possessed better tensile strength.

Choubey and Jatti (2014) [11] studied the effect of heat input controlled by welding current, arc voltage and welding speed on mechanical properties and microstructure of austenitic 202 type stainless steel weldments produced by SMAW. Author found that the tensile strength decreases with the increase in heat input and tensile test fractured surfaces shows ductile and brittle failure. High tensile strength and ductility at low heat input joint is attributed to smaller dendrite size and lesser inter-dendritic spacing in fusion zone.

Nauka et al. (2015) [12] reported the effect of welding current and filler metal on the percentage elongation of GTAW austenitic stainless steel weld joint. The $3 \mathrm{~mm}$ thick 304L austenitic stainless steel plate was welded by using 308L, 309L and 316L filler material with $2 \%$ thoriated non-consumable tungsten electrode and argon as shielding gas. It is concluded that percentage elongation is lower for all currents and filler metals than that of base materials. However, the values increases with the increase in welding current for all filler metal types.

David et al. (1995) [13] found that hot cracking can be prevented by small percentage of delta ferrite in austenitic stainless steel welds but it can lead to embrittlement of welds when exposed to elevated temperatures over a long period of time resulting change in microstructure.

Mukesh and Sanjeev (2013) [14] reported the effect of weld heat input on the mechanical properties of $6 \mathrm{~mm}$ thick square-butt weld joint of type 202 austenitic stainless steel produced by GTAW. Welding current was found to be most significant parameter that influenced the tensile strength and micro hardness.

\subsection{Problem Formulation}

After consulting the literature and key research papers, it has been found that little work has been reported related to deposition of the stainless steel weld with single V-joint configuration and approaching the joint from one side only. It has been observed after studying the literature review that the single $\mathrm{V}$-joint configuration necessitates the use of back purging arrangement to prevent the oxidation of weld metal at the rear side of the root. An inert gas should be used to protect the weld metal until it is cooled to the point that oxidation no longer can occur. 


\section{BACK PURGING DURING WELDING}

The welding of stainless steel and other corrosion resistant materials require perfect weld zone shielding against atmosphere during welding to achieve desired corrosion resistance. The heated weld zone oxidizes if it is exposed to air and shall no longer be resistant to corrosion. The oxidized material can be removed by grinding, brushing or pickling which restores the corrosion resistance $[4,8]$. However, in some cases such as pipe welding removing oxidized material after welding is difficult or impossible.

The shielding technique, which protects the rear side of the joint is called back purging. During welding, the heated weld metal at the root is exposed to air and oxidizes if it is not protected with back purging. An inert gas is used to protect the weld metal at the root until it is cooled to the point that oxidation no longer can occur. Back purging at the root enhances weld quality by improving weld surface appearance. Usually an inert gas, such as argon, which is heavier than air, is used. Other purging gases such as nitrogen, hydrogen and helium can also be used [4].

\subsection{Material}

The hot rolled austenitic stainless steel type 304L will be used as a base material. The microstructure of base material has been found consisting of equiaxed austenite grains having approximately the same dimension in all directions. The microstructure of base material has been shown in figure 2 .

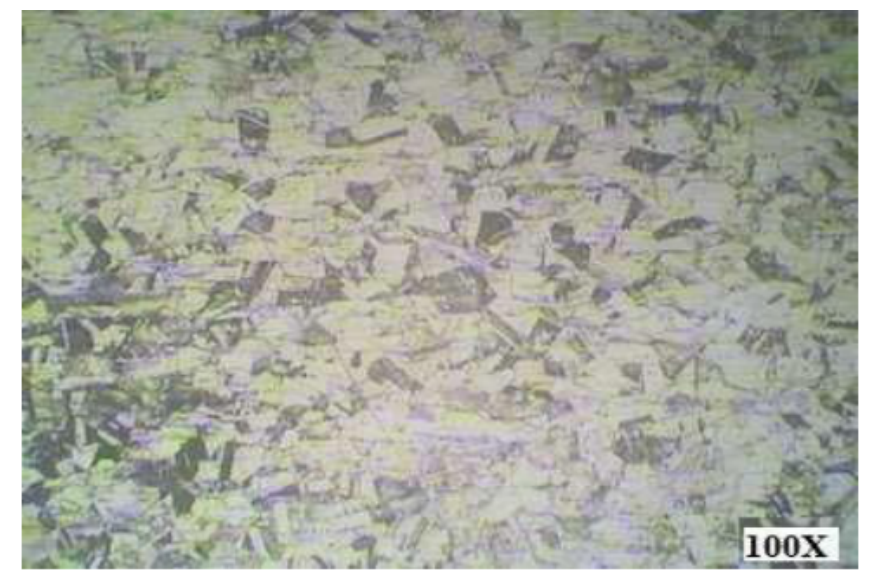

Figure 2 Microstructure of the base material

The mechanical properties of austenitic stainless steel type 304L are shown in table 1.

Table 1 The mechanical properties of austenitic stainless steel type 304L

\begin{tabular}{|c|c|}
\hline Properties & Values \\
\hline Yield strength $0.2 \%$ proof & $170 \mathrm{Mpa}$ \\
\hline Ultimate tensile strength & $484 \mathrm{Mpa}$ \\
\hline Percentage elongation $(\%$ in $50 \mathrm{~mm})$ & $40 \%$ \\
\hline Hardness & 227 (Vicker) \\
\hline Impact toughness at room temperature & $284 \mathrm{~J}$ \\
\hline
\end{tabular}

The chemical composition of filler wire and electrode are also detailed in table 2. Before welding, plate shall be cleaned from external surface dirt, oil, grease or paint. The naturally forming chromium oxide layer shall also be removed by stainless steel wire brush. Moisture and organic contaminants shall be eliminated. 
Table 2 Chemical composition of base and filler material [1]

\begin{tabular}{|l|c|c|c|c|c|c|c|}
\hline \multirow{2}{*}{ Material } & \multicolumn{7}{|c|}{ Chemical Composition (wt. \%) } \\
\cline { 2 - 8 } & $\mathbf{C r}$ & $\mathbf{N i}$ & $\mathbf{C}$ & $\mathbf{M n}$ & $\mathbf{S i}$ & $\mathbf{P}$ & $\mathbf{S}$ \\
\hline Base material 304L & 18.17 & 8.08 & 0.010 & 1.56 & 0.35 & 0.025 & 0.010 \\
\hline Wire 308L & 20.00 & 9.00 & 0.020 & 2.00 & 0.40 & 0.020 & 0.015 \\
\hline Electrode 308L-16 Rutile & 19.80 & 10.00 & 0.030 & 1.40 & 0.40 & - & - \\
\hline
\end{tabular}

\subsection{Back Purging Fixture}

Figure 3 shows the fixture for back purging. It was constructed out of a

thick mild steel plate by machining a recess in the center of steel plate as shown in figure 3 to fix a thick grooved copper plate. The holes of $1.5 \mathrm{~mm}$ diameter with counter shank of $3 \mathrm{~mm}$ diameter were drilled at the center of grooved copper plate for purging of argon gas to protect the underside of root pass. Two ports are provided. One for argon gas inlet and other for argon gas out let with pressure control knob.

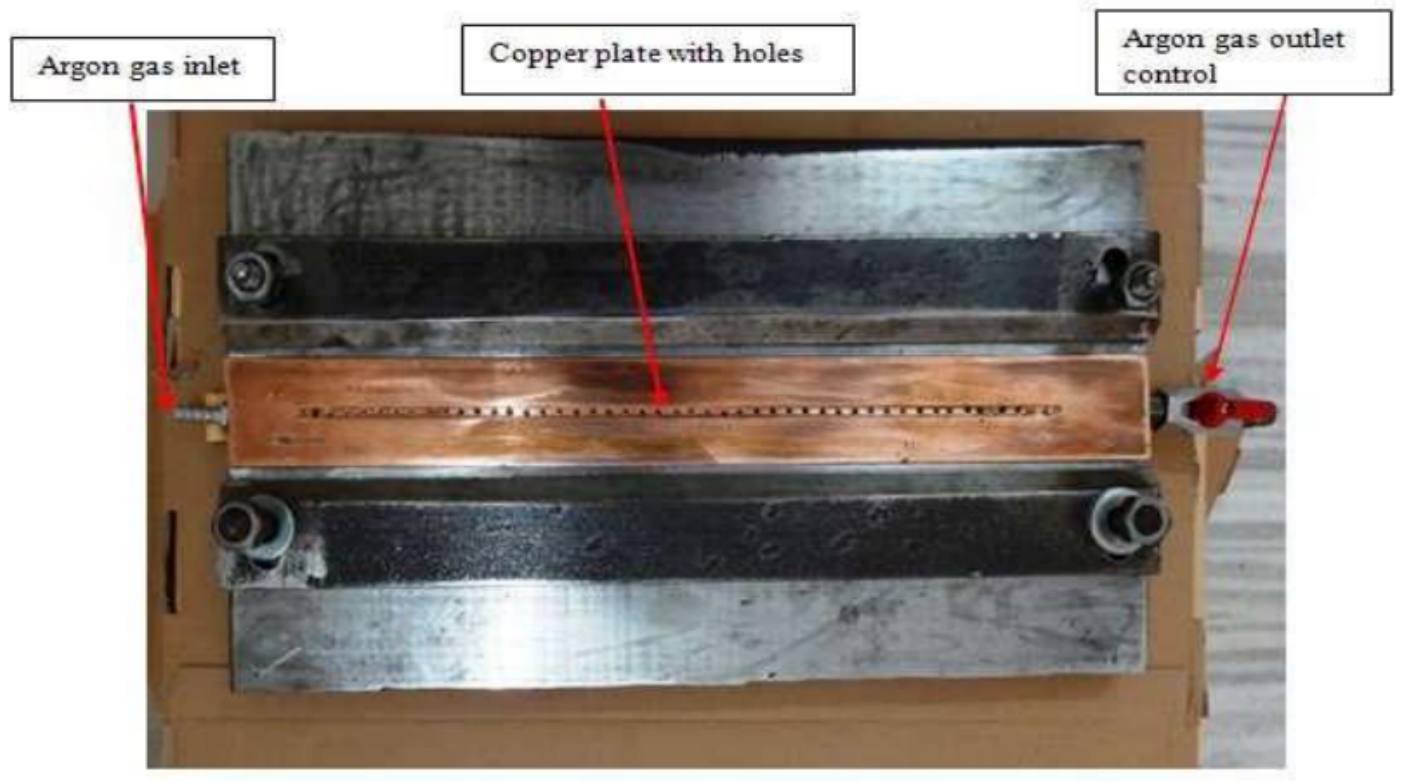

Figure 3 Fixture to hold the plates along with back purging arrangement.

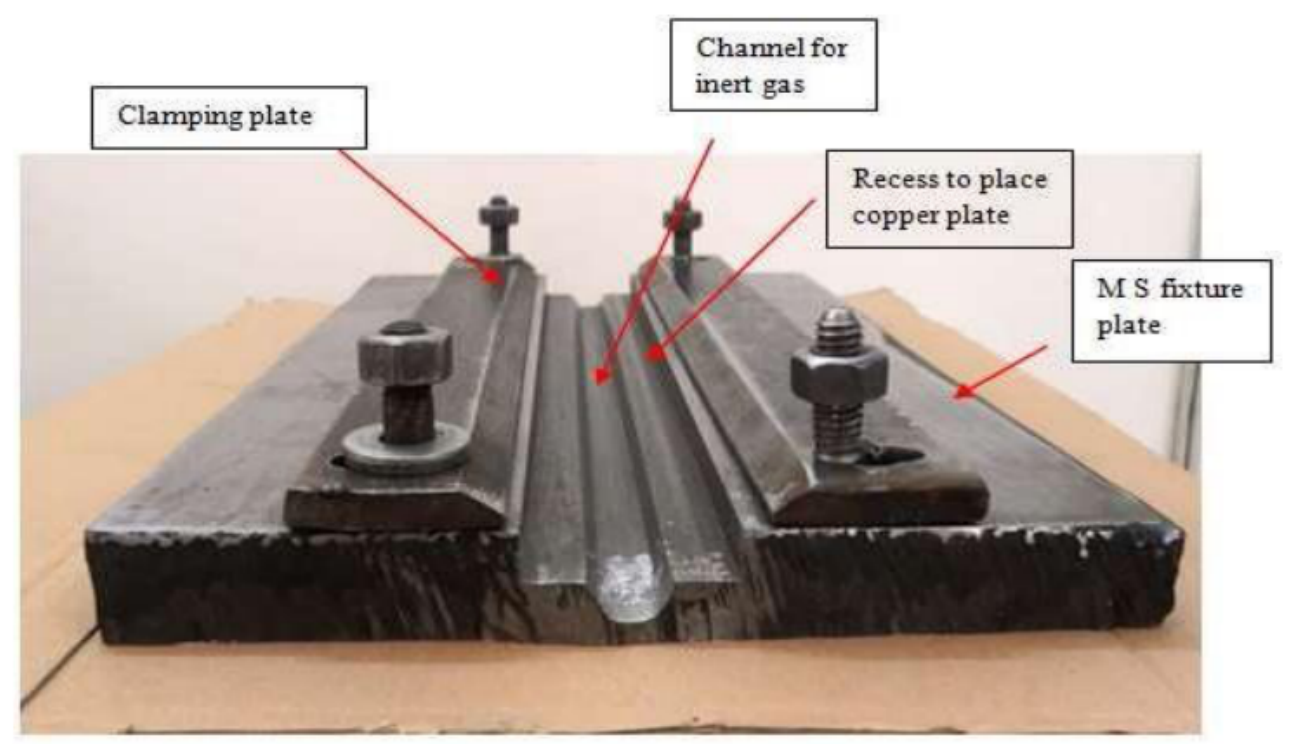

Figure 4 Mild steel base plate of fixture without copper plate 
Figure 4 shows the fixture without copper plate inserted in the recess. A channel for the flow of inert gas was mahined. The arrangements were also made to hold the welding plates firmly during welding.

Figure 5 shows the complete fixture along with the welding plates firmly held in the fixture. The plates to be welded are placed $3 \mathrm{~mm}$ apart so that proper fusion of root edges can take place during the welding.

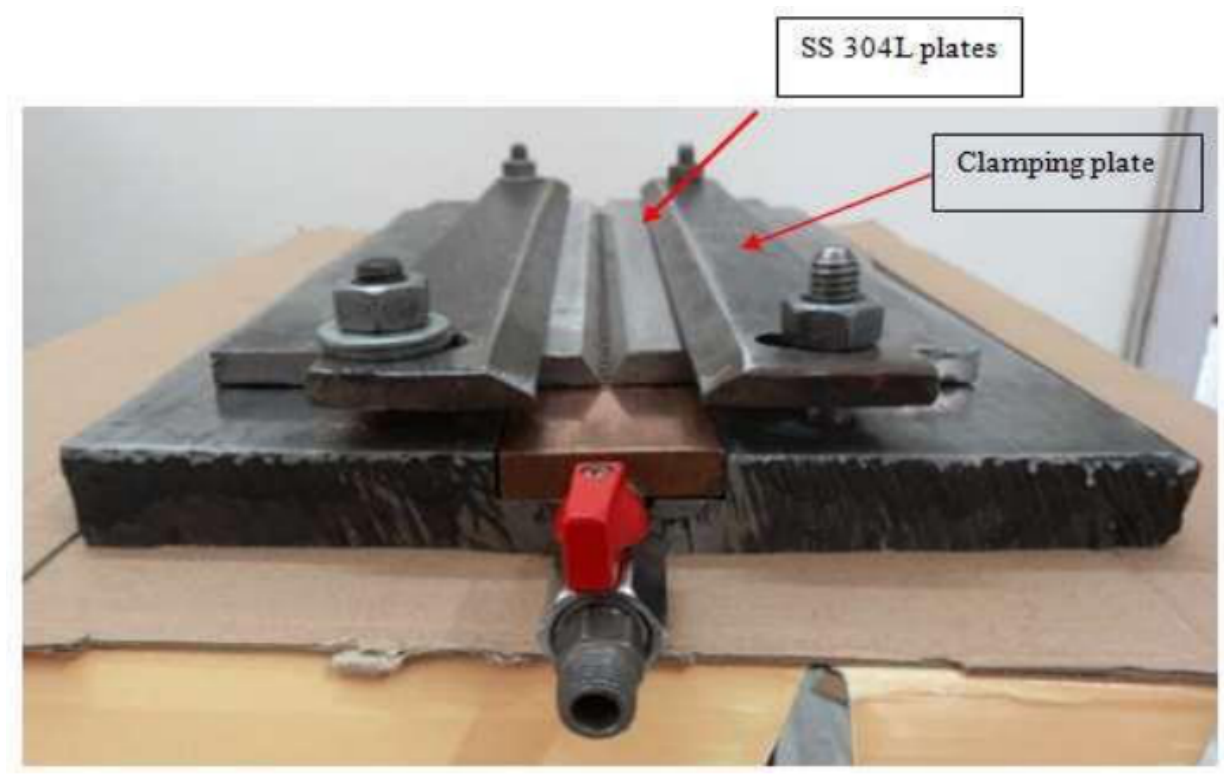

Figure 5 Fixture with back purging arrangement

\section{CONCLUSION AND FUTURE WORK}

In the present paper, a back purging apparatus has been developed to protect the rear side of the weld metal against oxidation. The back purging fixture was designed for the welding of austenitic stainless steel using SMAW welding process. The fixture has been developed to hold the plates firmly and to provide argon gas from rear side of the joint for back purging to protect the root weld metal from oxidation. An inert gas is used to protect the weld metal at the root until it is cooled to the point that oxidation no longer can occur. The authors are working further to study the effect of the designed fixture on the welding efficiency of austenitic stainless steel 304L.

\section{REFERENCES}

[1] Callister D. W., "Materials science and engineering", John Wiley \& Sons, $7^{\text {th }}$ Ed., New York, pp.167, 2007.

[2] Korinko P.S., Malene S.H., "Consideration for the weldability of types 304L and 316L stainless steel”, International American Society for Metals, 1(4), pp.61-68, 2001.

[3] Nadkarni S.V., "Modern arc welding technology", Oxford \& IBH Publishing Co. Pvt. Ltd. Bombay, $2^{\text {nd }}$ Ed., pp.24 -555, 1992.

[4] Damian K., Frank A., "Stainless steels welding guide", The Lincoln Electric Company, pp.1-37, 2003.

[5] Vinoth V., Madhavan R., Tharanitharan G., "Investigation on property relationship in various austenitic stainless steel 304L welds", International Journal of Scientific and Research Publications, 5, pp.1-4, 2015. 
[6] "Properties and Selection: Irons, Steels, and High Performance Alloys", ASM Handbook, International American Society for Metals, $10^{\text {th }}$ Ed., 1, pp.1394-1395, 1990.

[7] Jean P. J., "The welding of stainless steel”, European Market Development Association for Stainless Steel, 3, pp.3-26, 2007.

[8] Stout R. D., "Weldability of steels", Welding Research Council New York, $4^{\text {th }}$ Ed., pp.2427, 1987.

[9] Lancaster J.F., "Metallurgy of welding", Allen \& Unwin London, $4^{\text {th }}$ Ed., pp.239-241, 1987.

[10] Singh T., Shahi A.S., Kaur M., "Experimental studies on the effect of multipass welding on the mechanical properties AISI 304 stainless steel SMAW joints", International Journal of Scientific and Engineering Research, 4, pp.951-961, 2013.

[11] Choubey A., Jatti V. S., "Influence of heat input on mechanical properties and microstructure of austenitic 202 grade stainless steel weldments", World Scientific and Engineering Academy and Society, 9, pp.222-228, 2014.

[12] Nnuka E.E., Okonji P.O., Nwoye C.I., Akaluzia R.O., "Effect of welding current and filler metal types on percent elongation of GTAW austenitic stainless steel welds joints", Electronic Journal Management System, 2, pp.1-5, 2015.

[13] David S.A., Vitek J.M., Alexander D.J., "Embrittlement of austenitic stainless steel welds", Scientific and Technical Information, pp.1-8, 1995.

[14] Mukesh, Sharma S., "Study of mechanical properties in austenitic stainless steel using gas tungsten arc welding (GTAW)", International Journal of Engineering Research, 3, pp.547$553,2013$.

[15] American Society for Testing and Materials ASTM E8-15, "Standard Test Methods for Tension Testing of Metallic Materials".

[16] American Society for Testing and Materials ASTM E23-12, "Standard Test Methods for Notched Bar Impact Testing of Metallic Materials".

[17] American Society for testing and Materials ASTM e290-14, "Standard Test Methods for Bend Testing of Material for Ductility". 